\title{
Dimethylsulfoniopropionate in six species of giant clams and the evolution of dimethylsulfide after death ${ }^{1}$
}

\author{
Richard W. Hill, John W.H. Dacey, Susan D. Hill, Ahser Edward, and \\ Wayne A. Hicks
}

\begin{abstract}
Substantial accumulation of dimethylsulfoniopropionate (DMSP) is documented in tissues of all six of the common species of giant clams (Tridacnidae). Results include measures of DMSP concentrations in siphonal mantle, byssal mantle, adductor muscle, and gill tissues obtained by gas chromatography of alkalized extracts plus evidence of DMSP from mass spectrometry. Formation of dimethylsulfide (DMS) by tissues after death is documented. The tridacnid clams maintain symbiotic associations with populations of dinoflagellates, which live within the enlarged siphonal mantle. We postulated that because of their association with dinoflagellates, the clams would chronically accumulate DMSP to high concentrations. Our results show that DMSP occurs at over $30 \mathrm{mmol} \cdot \mathrm{kg}^{-1}$ in many tissues of tridacnid clams (sometimes 50-60 mmol $\cdot \mathrm{kg}^{-1}$ ), meaning that these clams accumulate DMSP to the highest documented tissue concentrations in the animal kingdom. DMSP at such concentrations could affect multiple properties and functions. Our particular interest for this research was to assess whether postmortem breakdown of DMSP is responsible for the rapid development of potent off-odors and off-tastes that have blocked the commercial success of giant clam aquaculture. High concentrations of DMS produced in the day after death probably account for the peculiar perishability of giant clam tissues.
\end{abstract}

\begin{abstract}
Résumé : Nous présentons des données qui montrent une accumulation importante de diméthylsulfoniopropionate (DMSP) dans les tissus des six espèces communes de moules géantes (Tridacnidae). Ces données comprennent des dosages des concentrations de DMSP par chromatographie en phase gazeuse d'extraits alcalinisés du manteau du siphon, du manteau du byssus, du muscle adducteur et des tissus branchiaux; d'autres données sur le DMSP ont été obtenues par spectrométrie de masse. Il y a aussi formation de sulfure de diméthyle (DMS) dans les tissus après la mort. Les moules tridacnidées maintiennent des relations symbiotiques avec des populations de dinoflagellés qui vivent dans le manteau élargi du siphon. Nous avons émis l'hypothèse que cette association avec les dinoflagellés amène les moules à accumuler de façon chronique de fortes concentrations de DMSP. Nos données confirment l'existence de concentrations de plus de $30 \mathrm{mmol} \cdot \mathrm{kg}^{-1}$ (même $50-60 \mathrm{mmol} \cdot \mathrm{kg}^{-1}$ ) dans plusieurs tissus des moules tridacnidées, ce qui représente les plus fortes accumulations tissulaires connues de DMSP dans le règne animal. À de telles concentrations, le DMSP doit affecter de nombreuses propriétés et fonctions. Nous nous sommes intéressés, en particulier, dans ce travail à savoir si la dégradation après la mort du DMSP est responsable de l'apparition rapide des fortes odeurs et des saveurs désagréables qui nuisent au succès commercial de l'élevage des moules géantes. Les fortes concentrations de DMS qui se produisent durant la première journée qui suit la mort des moules géantes expliquent probablement la détérioration inusitée de leurs tissus.
\end{abstract}

[Traduit par la Rédaction]

\section{Introduction}

Although dimethylsulfoniopropionate (DMSP) is ordinarily thought of as an algal compound, it could in principle accumulate to high concentrations in animals that live in symbi- otic association with algae. Such accumulation could have practical and physiological implications for the animals because DMSP can have important taste consequences in seafoods, can affect enzyme function, and may play roles in ameliorating tissue oxygen stress. We hypothesized that the

Received 1 February 2003. Accepted 7 November 2003. Published on the NRC Research Press Web site at http://cjfas.nrc.ca on 23 June 2004.

$\mathrm{J} 17362$

R.W. Hill ${ }^{2}$ and S.D. Hill. Department of Zoology, Michigan State University, East Lansing, MI 48824, U.S.A.

J.W.H. Dacey. Department of Biology, Woods Hole Oceanographic Institution, Woods Hole, MA 02543, U.S.A.

A. Edward. College of Micronesia - FSM, P.O. Box 159, Kolonia, Pohnpei, Federated States of Micronesia 96941.

W.A. Hicks. Department of Biochemistry and Molecular Biology, Michigan State University, East Lansing, MI 48824, U.S.A.

${ }^{1}$ This paper is part of the proceedings of the Third International Symposium on Biological and Environmental Chemistry of DMS(P) and Related Compounds, held in Rimouski (Québec), 26-28 September 2002.

${ }^{2}$ Corresponding author (e-mail: hillr@msu.edu). 
giant clams of the family Tridacnidae accumulate DMSP because they maintain symbiotic associations with dinoflagellates, termed zooxanthellae. The zooxanthellae, which belong to two of the major subdivisions of Symbiodinium (Rowan 1998), occur primarily in the siphonal mantle tissue, where they live and multiply extracellularly in a system of specialized tubules (Norton et al. 1992). The clams, which occupy exposed locations in the clear, shallow waters of IndoPacific coral reefs, present their extensive siphonal mantle tissue to the sun, enabling high photosynthetic rates by their zooxanthellae; the clams sometimes acquire over $90 \%$ of all of their organic carbon input from their zooxanthellae (Klumpp and Griffiths 1994), and evidence indicates that the zooxanthellae may meet at least $45 \%$ of the nitrogen requirements of the clams by manufacturing organic nitrogen compounds from ammonium nitrogen (Hawkins and Klumpp 1995). We recently reported for the first time that certain giant clams not only accumulate DMSP but also reach tissue concentrations higher than those documented for any other animals (Hill et al. 2000). Indeed, the concentrations of DMSP that we measured in giant clams were an order of magnitude higher than the highest tissue concentrations ever observed in fish, crustaceans, or other bivalve or gastropod mollusks, all of which, if they accumulate DMSP at all, acquire DMSP from ingested foods rather than endogenous symbionts (Hill et al. 2000).

A principal purpose of the present research was to enhance the definitiveness of our original report. For one thing, our earlier identification of DMSP was based entirely on gas chromatographic results (e.g., the column retention time of presumptive dimethylsulfide (DMS) liberated by alkalization of clam tissues matched the retention time of DMS reagent). In the research we now report, we returned tissues at liquid nitrogen temperature to the United States from western $\mathrm{Pa}-$ cific islands and analyzed these well-preserved materials by mass spectrometry as well as gas chromatography, providing definitive evidence for DMSP in the clam tissues. Another shortcoming of our earlier report was that only two of the eight or nine species of tridacnid clams were studied. In this report, we address all six of the common species in the family Tridacnidae.

Our second principal purpose in this research was to test our hypothesis (Hill et al. 2000) that DMS is evolved by giant clam tissues soon after death because of the postmortem breakdown of tissue DMSP. This hypothesis is of significant practical interest because giant clams are noted for developing offensive tastes and odors soon after death (Peavey and Riley 1993, 1994), and the off-tastes and off-odors have constituted significant obstacles for the commercial success of tridacnid aquaculture. We hypothesized that DMS, a well known agent of off-tastes in seafoods, is responsible for the problems observed with giant clams, the tissues of which are poised to generate substantial quantities of DMS because of their peculiarly high DMSP concentrations.

\section{Materials and methods}

\section{Tissues for study of chemical composition}

Hippopus hippopus (13-28 cm shell length), Tridacna maxima $(12-19 \mathrm{~cm})$, and Tridacna squamosa $(12-20 \mathrm{~cm})$ were collected in the wild and Tridacna derasa $(19-21 \mathrm{~cm})$ was obtained alive from government aquaculture facilities in the Federated States of Micronesia (Pohnpei and Kosrae); wild collection and export of tissues were by Permits Nos. 000304 and 00-001 from the Office of Marine and Coastal Resource Management, Pohnpei State Government. Hippopus hippopus (13-14 cm), Tridacna crocea $(7-9 \mathrm{~cm}), T$. derasa $(16-19 \mathrm{~cm})$, and Tridacna gigas $(12-17 \mathrm{~cm})$ were also obtained alive, mostly as aquacultured specimens, in the Republic of Palau from Belau Aquaculture; export of tissues was by certificate EXP.2000-102 from the Ministry of Resources and Development, Republic of Palau.

Tissues were taken from clams immediately after death in the Federated States of Micronesia and Palau in March 2000. A siphonal mantle sample was cut from the middle of the siphonal mantle of each clam; the cuts were made through the entire tissue and perpendicular to the tissue surface so as to include the pigmented surface layer and the relatively unpigmented inner layer of this mantle tissue in their natural proportions. A byssal mantle sample was cut in a similar manner from the mantle tissue near the byssal aperture, tissue that does not receive sunlight. The sample of adductor muscle was cut from the interior of the muscle. Cuts for the gill sample were made perpendicular to the long axis of a gill so as to include the full lengths of the gill lamellae. All samples were blotted on paper towels and weighed promptly after being cut. Samples were then placed in Corning cryogenic vials (polypropylene) and frozen immediately using dry ice. They were later transferred to an MVE dry dewar at liquid nitrogen temperature for transport to the United States where they were refrigerated at $-80{ }^{\circ} \mathrm{C}$ until assay by mass spectrometry, gas chromatography, and fluorometry (for pheophytin).

\section{Chemical assays}

For mass spectrometry, an approximately $0.7-\mathrm{g}$ piece of tissue was powdered by grinding in a mortar at liquid nitrogen temperature and extracted twice into a methanol-chloroformwater solution (12:5:1). Separation of the solution into aqueous and chloroform phases was then induced. The aqueous phase was removed, acidified $(\mathrm{HCl})$, enriched with $10 \mu \mathrm{mol}$ of trigonelline (Sigma; 1-methylpyridinium-3-carboxylate) as a semiquantitative internal standard, and passed sequentially through three resin columns: (i) Bio-Rad Laboratories AG 1-X8 (200-400 mesh, $\mathrm{Cl}^{-}$form) prepared by washing to equilibrium with $1 \mathrm{~mol} \cdot \mathrm{L}^{-1} \mathrm{NaOH}$, (ii) Bio-Rad Bio-Rex 70 (100-200 mesh, $\mathrm{Na}^{+}$form) previously protonated by washing with $1 \mathrm{~mol} \cdot \mathrm{L}^{-1} \mathrm{HCl}$, and (iii) Bio-Rad AG 50W-X8 (200-400 mesh, $\mathrm{Na}^{+}$form) previously protonated by washing with $1 \mathrm{~mol} \cdot \mathrm{L}^{-1} \mathrm{HCl}$. Distilled, deionized water was passed through the columns following the sample. Afterward, the AG 50 column was eluted with $2.5 \mathrm{~mol} \cdot \mathrm{L}^{-1} \mathrm{HCl}$. The elution solution was lyophilized and stored at $-20{ }^{\circ} \mathrm{C}$ until a fast atom bombardment mass spectrum was obtained using a Jeol JMF HX 110 mass spectrometer. An index of DMSP concentration was calculated as the ratio of the mass135 signal over the mass-138 signal (trigonelline) normalized to the weight of tissue assayed.

For analysis by gas chromatography and fluorometry, an approximately $1-\mathrm{g}$ piece of tissue was minced while still semifrozen and placed in $25 \mathrm{~mL}$ of reagent-grade methanol in a glass vial sealed with a Teflon-faced butyl-rubber sep- 
Table 1. Concentration of DMSP $\left(\mu \mathrm{mol} \cdot \mathrm{g}^{-1}\right)$ in four tissues of six species of giant clams.

\begin{tabular}{|c|c|c|c|c|c|c|c|c|}
\hline \multirow[b]{2}{*}{ Species } & \multicolumn{2}{|c|}{ Siphonal mantle } & \multicolumn{2}{|c|}{ Byssal mantle } & \multicolumn{2}{|c|}{ Adductor muscle } & \multicolumn{2}{|l|}{ Gill } \\
\hline & Mean \pm SE & Range & Mean $\pm \mathrm{SE}$ & Range & Mean \pm SE & Range & Mean \pm SE & Range \\
\hline H. hippopus $(n=8)$ & $6.76 \pm 1.54$ & $1.5-15.7$ & $9.67 \pm 1.50$ & $3.4-16.4$ & $3.95 \pm 1.07$ & $1.2-9.5$ & $17.6 \pm 7.51$ & $7.0-47.4$ \\
\hline T. derasa $(n=9)$ & $16.5 \pm 2.33$ & $6.0-27.1$ & $11.9 \pm 1.09$ & $7.2-16.6$ & $5.75 \pm 1.64$ & $1.4-13.9$ & $7.83 \pm 0.47$ & $6.3-8.8$ \\
\hline T. gigas $(n=7)$ & $25.9 \pm 1.47$ & $21.5-32.4$ & $17.3 \pm 1.73$ & $11.7-23.4$ & $10.7 \pm 1.92$ & $4.8-16.9$ & $22.5 \pm 1.39$ & $18.5-26.1$ \\
\hline T. $\operatorname{maxima}(n=7)$ & $29.6 \pm 3.20$ & $15.4-41.5$ & $29.9 \pm 4.05$ & $14.7-42.7$ & $3.29 \pm 0.20$ & $2.4-3.8$ & $34.7 \pm 2.24$ & $27.0-41.4$ \\
\hline
\end{tabular}

Note: Adductor muscle for one T. derasa was not analyzed. For gill, $n$ is 5 for $H$. hippopus, 1 for $T$. crocea, 5 for $T$. derasa, and 5 for $T$. gigas, and as tabulated for the other species.

tum (Regis Technology). After $24 \mathrm{~h}$ of extraction in the dark with periodic shaking, $1.0 \mathrm{~mL}$ of methanol was withdrawn by glass syringe from each tissue extraction vial and placed in $25 \mathrm{~mL}$ of $2 \mathrm{~mol} \cdot \mathrm{L}^{-1} \mathrm{KOH}$ in a sealed analysis glass vial. Incubation in cold base quantitatively converts DMSP to DMS (Dacey and Blough 1987). After base incubation, DMS was measured in headspace samples by gas chromatography using a Chromosil 330 (Supelco) column for separation, Sievers 350B sulfur chemiluminescence detector, and Hewlett Packard 3395 integrator. Standards were prepared in $25 \mathrm{~mL}$ of $2 \mathrm{~mol} \cdot \mathrm{L}^{-1} \mathrm{KOH}$ plus $1 \mathrm{~mL}$ of methanol using reagent-grade DMS (Fluka) in vials identical to those used for alkalization of tissue extracts.

Chlorophyll was measured to serve as an index of the density of zooxanthellae. In fact, because some chlorophyll could have degraded to pheophytin during shipment and sample preparation, and because our interest was not in chlorophyll itself but in an index of relative levels of zooxanthellae, we degraded all chlorophyll by acidification $\left(3 \mathrm{mmol} \mathrm{HCl} \cdot \mathrm{L}^{-1}\right)$ and measured total pheopigment levels as our index (Hill et al. 1995). For pheopigment assay, $0.5 \mathrm{~mL}$ of methanol was withdrawn by glass syringe from each tissue extraction vial (as earlier described) and placed in $6.5 \mathrm{~mL}$ of reagent-grade methanol. Additional serial dilutions were carried out in methanol if necessary to place a sample onto the linear portion of the calibration curve. Pheopigment $a$ was measured using a Turner 10-AU fluorometer calibrated using standards of chlorophyll $a$ from spinach (Sigma) in methanol (acidified exactly as unknowns) following procedures recommended by Holm-Hansen and Riemann (1978).

\section{Postmortem DMS production}

DMS production by tissues of T. maxima and T. squamosa after death was studied in August and September 2000 in Pohnpei and Palau using an HNU Systems PI-52 photoionization detector, Chromosil 330 column, and Hewlett Packard 3395 integrator transported to Pohnpei and Palau and operated with air from scuba tanks. Clams collected without injury (e.g., by chiseling out of coral rock with byssus intact) and maintained in running seawater after collection were killed at a defined moment within 10-20 h of collection. Pieces of adductor muscle and siphonal mantle tissue were placed in glass vials closed with Teflon-faced septa and sealed with crimped aluminum rings. Gas was periodically removed for analysis. For calibration, we injected headspace samples from standards of reagent-grade DMS (Fluka) in $2 \mathrm{~mol} \cdot \mathrm{L}^{-1} \mathrm{KOH}$. To determine absolute DMS con- centrations in the headspaces of the standards, exact replicates of the standards were prepared in Woods Hole and calibrated, at temperatures matching those in Pohnpei and Palau, against a VICI Metronics DMS permeation tube that was factory calibrated to U.S. National Institute of Standards and Technology standards.

Total DMSP in the tissues used for the postmortem DMS study in Palau was measured by extracting samples of the tissues in $75 \%$ ethanol. Ethanol was used in these assays because ethanol was locally available, whereas methanol was not. Samples of the extracts were alkalized in $2 \mathrm{~mol} \cdot \mathrm{L}^{-1}$ $\mathrm{KOH}$ and assayed much as described earlier for total tissue DMSP using standards prepared in a background of $2 \mathrm{~mol} \cdot \mathrm{L}^{-1}$ $\mathrm{KOH}$ and ethanol.

\section{Results}

\section{Chemical assays}

Tridacna maxima and T. squamosa exhibited the pattern of tissue DMSP concentrations reported for the species in earlier research (Hill et al. 2000) in that the siphonal mantle, byssal mantle, and gill tissue were similar to each other in DMSP concentration and over five times more concentrated in DMSP than the adductor muscle (Table 1). This pattern appears to be consistent for these species, as we have also observed it in other data collections not yet reported. The present research reveals that the pattern also exists in $T$. crocea. However, in $T$. derasa, $T$. gigas, and H. hippopus, although the adductor muscle is least concentrated in DMSP, the difference between it and other tissues is not as dramatic, and in $H$. hippopus, there is only one tissue that is dramatically high in DMSP, the gill.

Judging from our data on pheophytin $a$, the byssal mantle tissue, which occurs along the shell margins farthest from the light-exposed part of the mantle, is always far less concentrated in chlorophyll than the siphonal mantle tissue, which houses the principal population of zooxanthellae and is presented to the sun (Table 2). The adductor muscle and gill are almost devoid of chlorophyll in all six species of giant clams.

A point of particular interest is whether DMSP occurs at high concentrations in the animal tissues of the clams as opposed to being simply associated with algal cells positioned within the animal tissues. Abundant evidence indicates, in fact, that DMSP occurs in the animal tissues. For example, in $T$. crocea, $T$. maxima, and $T$. squamosa, the byssal mantle is at least as concentrated in DMSP as the siphonal mantle 
Table 2. Concentration of pheophytin $a\left(\mu \mathrm{g} \cdot \mathrm{g}^{-1}\right.$, mean $\left.\pm \mathrm{SE}\right)$ in four tissues of six species of giant clams.

\begin{tabular}{lllll}
\hline Species & Siphonal mantle & Byssal mantle & Adductor muscle & Gill \\
\hline H. hippopus $(n=8)$ & $245 \pm 49.6$ & $89.7 \pm 27.3$ & $5.82 \pm 2.5$ & $0.74 \pm 0.5$ \\
T. crocea $(n=6)$ & $530 \pm 64.8$ & $15.8 \pm 10.4$ & $2.51 \pm 0.8$ & 1.96 \\
T. derasa $(n=9)$ & $174 \pm 33.0$ & $15.0 \pm 6.8$ & $0.34 \pm 0.2$ & $0.21 \pm 0.1$ \\
T. gigas $(n=7)$ & $205 \pm 20.3$ & $39.0 \pm 8.6$ & $8.61 \pm 1.5$ & $3.78 \pm 1.2$ \\
T. maxima $(n=7)$ & $283 \pm 37.8$ & $23.3 \pm 6.7$ & $1.38 \pm 0.3$ & $2.18 \pm 0.9$ \\
T. squamosa $(n=5)$ & $431 \pm 70.5$ & $48.8 \pm 26.5$ & $2.15 \pm 0.5$ & $7.83 \pm 5.7$ \\
\hline
\end{tabular}

Note: Adductor muscle for one T. derasa was not analyzed. For gill, $n$ is 5 for H. hippopus, 1 for T. crocea, 5 for $T$. derasa, 5 for $T$. gigas, and as tabulated for the other species.

Fig. 1. DMSP concentration as a function of pheophytin $a$ concentration for all 154 tissue samples analyzed by both methods. Symbols identify tissue type: $\boldsymbol{\Theta}$, siphonal mantle; $\bigcirc$, byssal mantle; $\boldsymbol{\Delta}$, adductor; $\triangle$, gill.

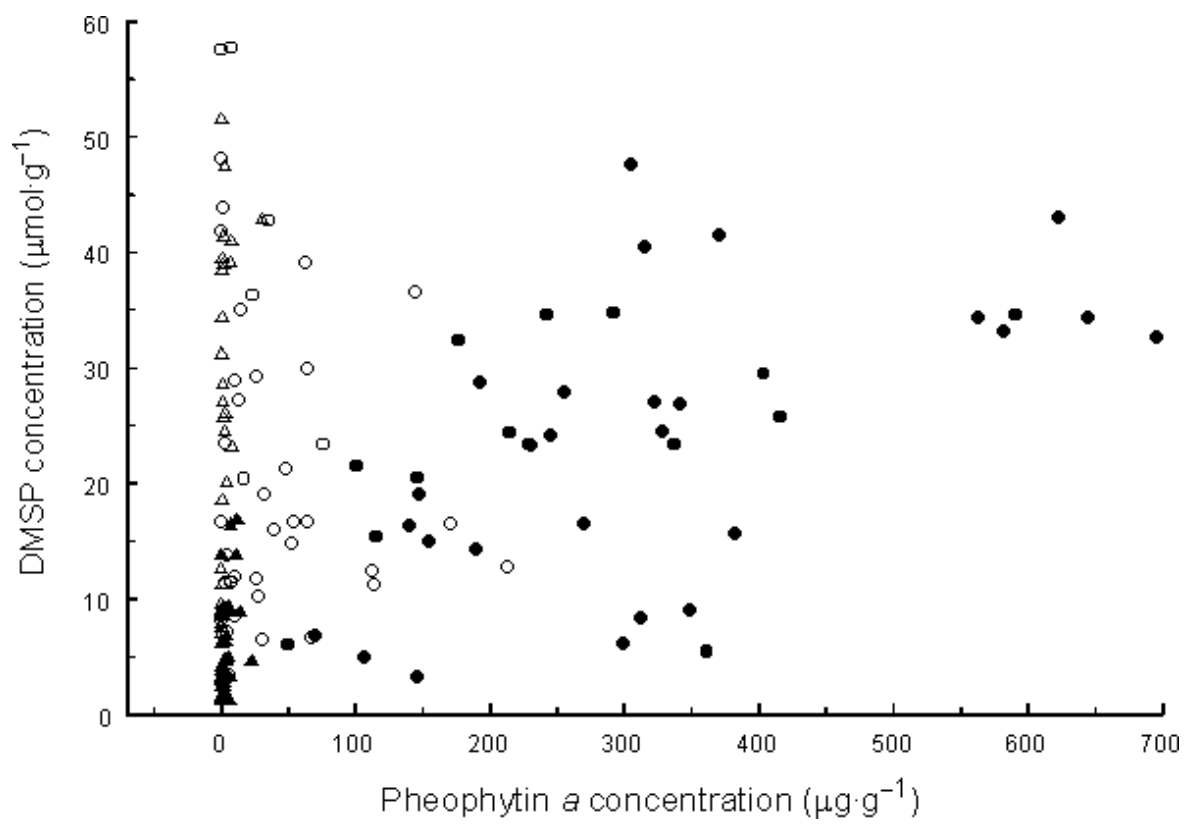

(Table 1), even though, on average, its concentration of chlorophyll is only $3-11 \%$ as high as that of the siphonal mantle. The data on the byssal mantle indicate that a tissue may contain a high concentration of DMSP without having a high density of zooxanthellae. Similarly, the gills often have high concentrations of DMSP while being virtually devoid of zooxanthellae. Overall, the DMSP concentration of tissues bears little predictable relationship to the density of zooxanthellae in the tissues (as gauged by chlorophyll concentration) (Fig. 1). The correlation between the two variables is statistically significant $(r=0.58, p<0.01, n=42)$ for siphonal mantle, and that relationship seems to be principally responsible for the fact that the correlation for all tissues taken together is statistically significant $(r=0.30, p<$ $0.01, n=154)$. However, low chlorophyll concentrations do not at all preclude high DMSP concentrations. (For tissues other than siphonal mantle, $r=0.08$, indicating a nonsignificant correlation, but the analysis using $r$ is of qualitative use only because the data are so heteroscedastic.)

Mass spectra were obtained for 57 tissue samples representing all six species in approximately equal numbers and representing the siphonal mantle, byssal mantle, and adductor tissues in approximately equal numbers. A signa- ture was observed at mass 135 in essentially every sample analyzed, documenting the presence of DMSP. The only sample that did not exhibit a mass-135 signature was one that gas chromatography indicated was virtually devoid of DMSP. Overall, a rough correlation exists between the magnitude of the signature at mass 135 and the DMSP concentration measured by gas chromatography (Fig. 2) (the correlation coefficient is not calculated because of the extreme heteroscedasticity of the data). An important result from the mass spectrometry of the samples eluted from the Bio-Rex 70 resin was the absence from all samples of a signature at mass 164 , indicating that the tissues of giant clams contain little or no $S$-methylmethionine.

\section{Postmortem DMS production}

Following death, significant DMS production often occurs from the siphonal mantle tissue of $T$. maxima and T. squamosa within the first $10 \mathrm{~h}$, and within $24 \mathrm{~h}$, a marked efflux of DMS from siphonal mantle is universal (Figs. 3 and 4). On the other hand, some samples of adductor muscle evolve almost no DMS even after 24-48 h, and the samples of adductor muscle that produce significant DMS inevitably produce far less than siphonal mantle tissue from the same 
Fig. 2. Index of DMSP concentration from mass spectrometry as a function of the DMSP concentration from gas chromatography in 57 samples analyzed by both methods. The index of DMSP concentration from mass spectra was calculated as the magnitude of the mass-135 signal divided by the magnitude of the trigonelline signal normalized for the weight of the tissue sample analyzed.

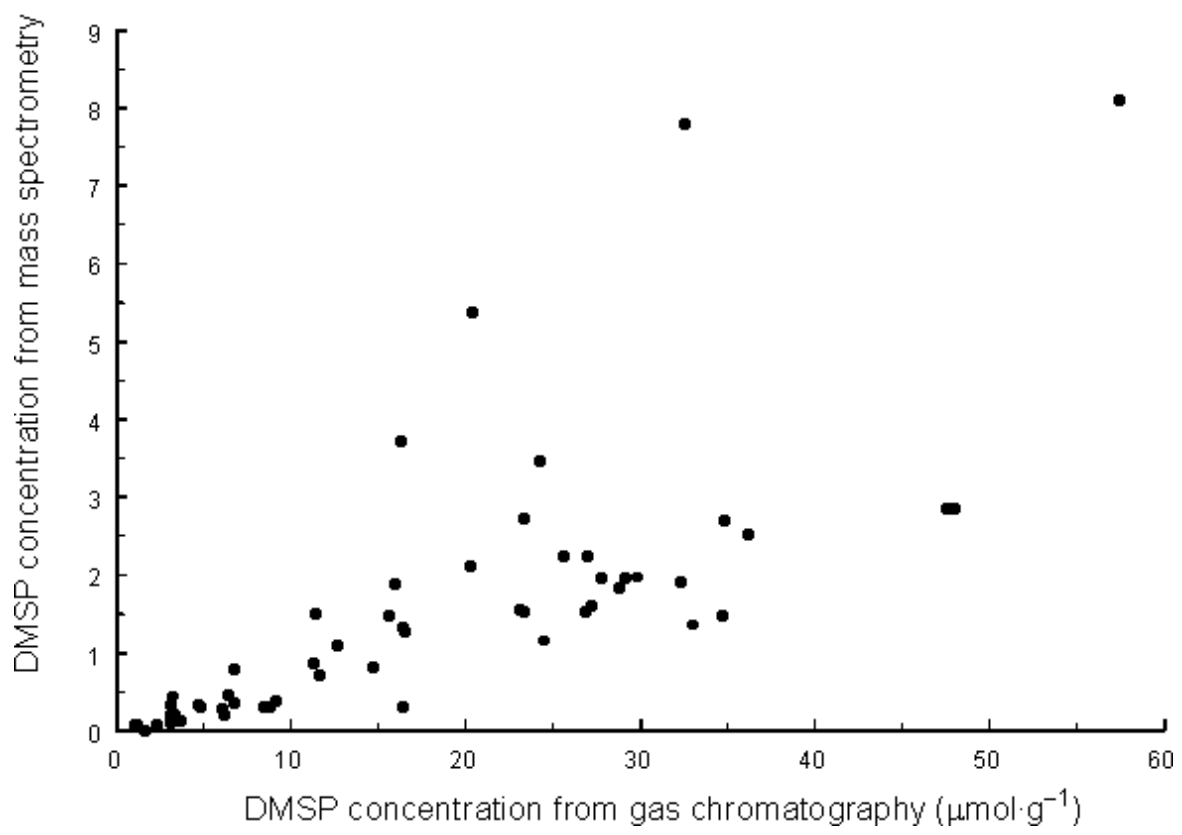

Fig. 3. Accumulation of DMS in sealed vials containing pieces of siphonal mantle tissue (solid symbols) and adductor muscle tissue (open symbols) of four T. maxima (11-21 cm shell length) and two T. squamosa $(11-15 \mathrm{~cm})$ collected in Pohnpei as a function of time after death. Each piece of tissue weighed about $3 \mathrm{~g}$ and was sealed in a $38-\mathrm{mL}$ vial. The temperature was $25-30{ }^{\circ} \mathrm{C}$. Solid and open symbols are matched for individual clams. The lowermost squares and triangles represent T. squamosa.

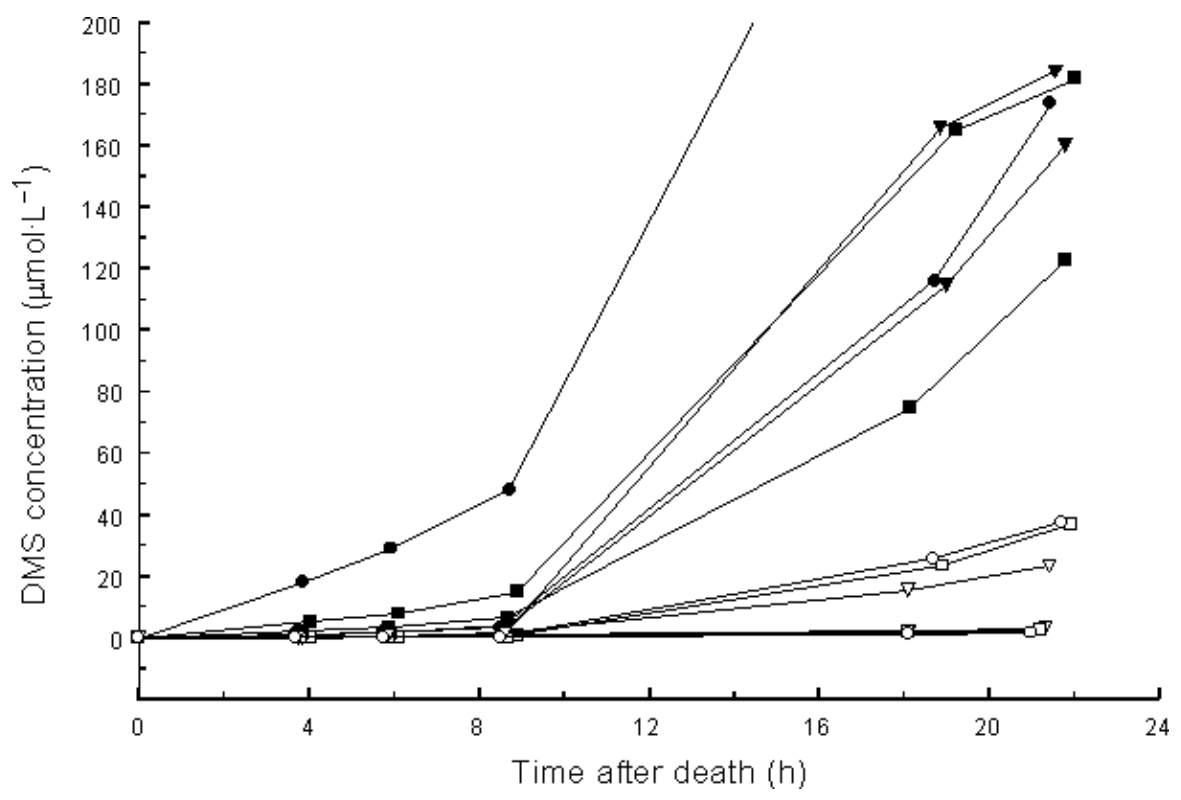

animal (Figs. 3 and 4). At 20-25 h, the quantity of DMS accumulated in the gas phase in the vials containing siphonal mantle samples (Fig. 4) was 310-2700 $\mathrm{nmol} \cdot \mathrm{g}^{-1}$, whereas our assays of the same siphonal tissues by alcohol extraction

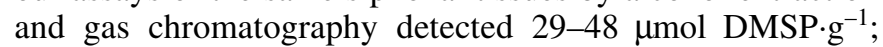
the DMS accumulated in the gas phase of adductor samples was $8-240 \mathrm{nmol} \cdot \mathrm{g}^{-1}$, whereas the adductor samples contained 1-20 $\mu \mathrm{mol}$ DMSP.g ${ }^{-1}$. Thus, the fraction of DMSP accumulated in net fashion as DMS gas was not great. At 21-22 h, the quantity of DMS accumulated in the gas phase in the siphonal mantle vials was $1600-2400 \mathrm{nmol} \cdot \mathrm{g}^{-1}$, whereas that accumulated in adductor muscle vials was 18$450 \mathrm{nmol} \cdot \mathrm{g}^{-1}$ (Fig. 3).

\section{Discussion}

The preponderance of evidence indicates that for the tridacnid clams, a chronic accumulation of DMSP in many of their tissues is a special consequence of their symbiotic association with dinoflagellates. DMSP occurs in tissues that 
Fig. 4. Accumulation of DMS in sealed vials containing pieces of siphonal mantle tissue (solid symbols) and adductor muscle tissue (open symbols) of three T. maxima (13-21 cm shell length) and five T. squamosa $(19-26 \mathrm{~cm})$ collected in Palau as a function of time after death. Each piece of tissue weighed about $1 \mathrm{~g}$ and was sealed in an $11-\mathrm{mL}$ vial. The temperature was around $5{ }^{\circ} \mathrm{C}$ for the first $6 \mathrm{~h}$ but thereafter was about $30{ }^{\circ} \mathrm{C}$. Solid and open symbols are matched for individual clams. Tridacna maxima are represented by the uppermost circles, squares, and diamonds for siphonal mantle tissue and by the uppermost circles and squares and lowermost diamonds for adductor muscle tissue.

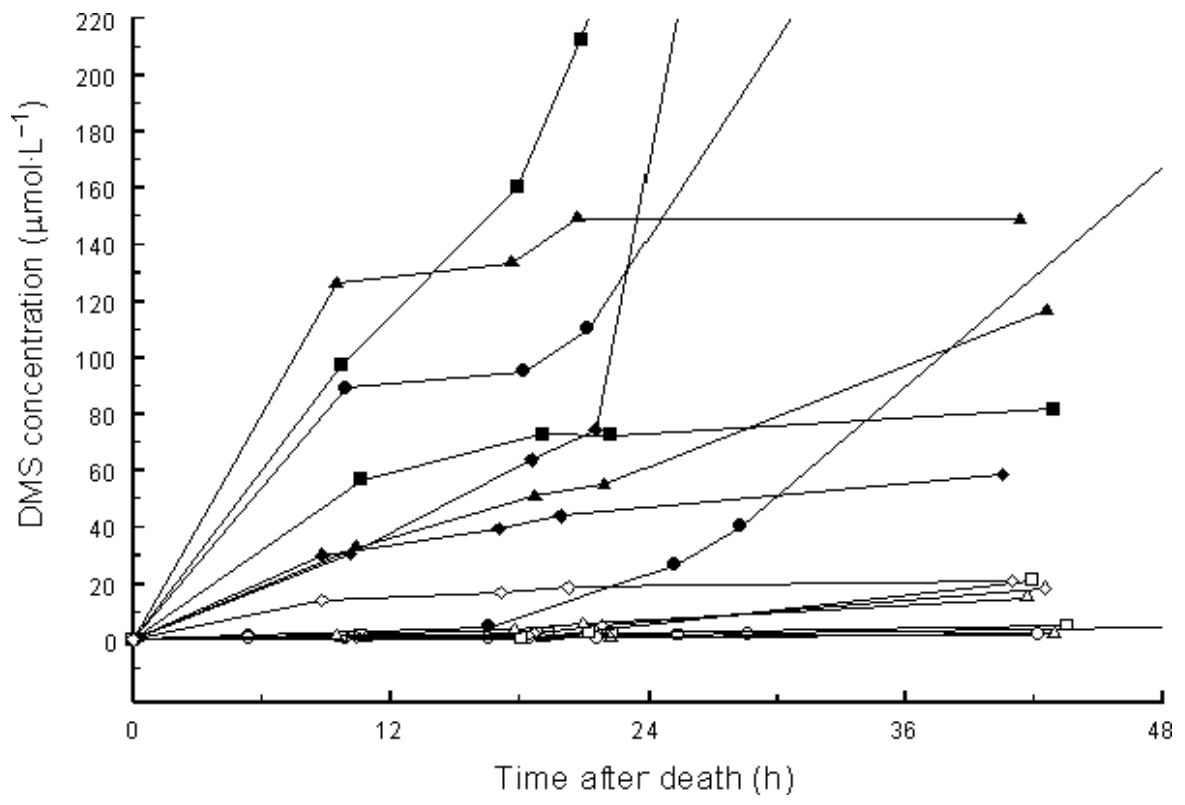

harbor few, if any, zooxanthellae, indicating that DMSP is transported throughout the clams from the siphonal mantle, where photosynthesis occurs, along with nutritional and other algal products. The evidence for DMSP in the tissues of the clams is twofold, namely that a mass-135 signature is a virtually universal feature of the mass spectra of giant clam tissues and that alkalization at room temperature very rapidly gives rise to DMS; furthermore, the mass spectra indicate that giant clam tissues are free of $S$-methylmethionine, an unlikely but theoretically possible alternative source of DMS. An intriguing attribute of the distribution of DMSP within individual clams is that the various tissues of single individuals often differ dramatically in DMSP concentrations. This research expands knowledge of the heterogeneous nature of DMSP accumulation by bringing to light that species differ in systematic ways in their patterns of DMSP distribution within individuals (Table 1). If DMSP has metabolic or other consequences for the tissues in which it occurs, the pattern of DMSP distribution within a clam's body could be subject to adaptive evolution. The adductor muscle, to take the example of a particular tissue, is consistently low in DMSP concentration. Is this a passive consequence of the tissue structure and composition of adductor muscle, or has adductor muscle evolved properties that specifically act to exclude DMSP? There seems to be no basis for deciding at present.

The tissue concentrations of DMSP observed in giant clams are extraordinary for animals. Hill et al. (2000) reviewed the literature on DMSP in animals and found that values reported for fish, crustaceans, and other mollusks, all of which acquire DMSP through food ingestion, are essentially always below $3-4 \mu \mathrm{mol} \cdot \mathrm{g}^{-1}$. About the only exception is a single reported instance of $30-40 \mu \mathrm{mol} \cdot \mathrm{g}^{-1}$ in pteropods
(Levasseur et al. 1994), but this case is not directly comparable with the sort of data reported here because, of necessity, the pteropod assay included gut contents and thus did not directly reveal tissue concentrations. In giant clams, even disregarding the siphonal mantle where abundant algal DMSP is presumably confounded with animal tissue DMSP, concentrations of DMSP of $30 \mu \mathrm{mol} \cdot \mathrm{g}^{-1}$ or higher are commonplace, and values as high as $40-60 \mu \mathrm{mol} \cdot \mathrm{g}^{-1}$ are regularly encountered. Animals that have evolved symbioses with microbes can potentially accumulate unusual concentrations of microbial products. The giant clams seem to represent the most extreme case of accumulation of DMSP.

There are three ways in which a plausible case can presently be made that DMSP in giant clam tissues could have significant consequences. First, as stressed already by Hill et al. (2000), evidence exists that DMSP at the concentrations observed could perturb the function of certain enzymes (Nishiguchi and Somero 1992; Karsten et al. 1996). Because of the potential for such effects, giant clams might have evolved specialized enzyme forms differing from the enzyme homologs in other mollusks, notably enzyme forms adapted to function within a high-DMSP environment. A second potential consequence of the presence of high DMSP concentrations is that, according to some evidence, DMSP and DMS are capable of acting to ameliorate tissue oxygen stress (Sunda et al. 2002). The tridacnid clams face the challenge that they expose their siphonal mantle tissue to high insolation at high water temperatures so as to provide their algal symbionts with sunlight, and furthermore, the clams have vigorous photosynthetic activity proceeding within the substance of their siphonal mantle tissue. Just as the algae might themselves benefit from compounds that ameliorate oxygen stress, the animal tissues of the clams might also 
benefit. If DMSP and DMS can help relieve oxygen stress, they could play adaptive roles in clam tissues.

With the publication of this research, the third potential consequence of high DMSP concentrations in tridacnid tissues is the best established. A major reason that the aquaculture of giant clams in western Pacific nations has failed is that their meat is exceptionally perishable because of the rapid postmortem development of a "particularly offensive and pervasive odor", even if the clams are refrigerated with the viscera removed (Peavey and Riley 1993, 1994). Comparing siphonal mantle and adductor meat, a disagreeable "seaweed-like" odor has been particularly associated with the mantle (Cowan 1988), and the mantle is far less commercially valuable than the adductor (Hill et al. 2000). On the island of Pohnpei, the government aquaculture project persuaded several up-scale restaurants catering to tourists to carry cultured tridacnids on their menus, but the venture ended when restaurant owners factored in that the clams needed to be kept alive until served because of their peculiar tendency to develop off-tastes and off-odors soon after death. Based on the data we here present and our experiences with the odors of dead tridacnids, we believe that the postmortem evolution of DMS from tissue DMSP is the cause of this problem. To put the problem in perspective, tissue concentrations of DMSP in cod and other finfish in the range of $0.2-1.0 \mu \mathrm{mol} \cdot \mathrm{g}^{-1}$ are considered high and commercially problematic because of the offensive odors that can be caused by postmortem DMS formation (Hill et al. 2000); even the adductor muscles of giant clams contain higher concentrations. Knowing the cause of the postmortem offtastes and off-odors in giant clams sets the stage for a rational approach to a solution to the problem (e.g., development of chemically specific methods to prevent DMS formation). The offensive tastes and smells are a consequence of the symbiotic association of these remarkable animals with algae, a relationship that during life provides the clams with beneficial access to photosynthetic products.

\section{Acknowledgements}

Douglas Gage, Mark Dennett, and David Kulis assisted with chemical analyses. Larry Sharron helped procure clams in Palau. This study was funded by the Comer Science and Education Foundation, Michigan Sea Grant, and Woods Hole Oceanographic Institution Sea Grant. This is Woods Hole Oceanographic Institution contribution No. 10821.

\section{References}

Cowan, L. 1988. Use of giant clams in Japanese cuisine. In Giant clams in Asia and the Pacific. Edited by J.W. Copland and J.S.
Lucas. Australian Centre for International Agricultural Research, Canberra, Australia. pp. 256-257.

Dacey, J.W.H., and Blough, N.V. 1987. Hydroxide decomposition of dimethylsulfoniopropionate to form dimethylsulfide. Geophys. Res. Lett. 14: 1246-1249.

Hawkins, A.J.S., and Klumpp, D.W. 1995. Nutrition of the giant clam Tridacna gigas (L.). 2. Relative contributions of filterfeeding and the ammonium-nitrogen acquired and recycled by symbiotic algae towards total nitrogen requirements for tissue growth and metabolism. J. Exp. Mar. Biol. Ecol. 190: 263-290.

Hill, R.W., Dacey, J.W.H., and Krupp, D.A. 1995. Dimethylsulfoniopropionate in reef corals. Bull. Mar. Sci. 57: 489-494.

Hill, R.W., Dacey, J.W.H., and Edward, A. 2000. Dimethylsulfoniopropionate in giant clams (Tridacnidae). Biol. Bull. (Woods Hole), 199: 108-115.

Holm-Hansen, O., and Riemann, B. 1978. Chlorophyll $a$ determination: improvements in methodology. Oikos, 30: 438-447.

Karsten, U., Kück, K., Vogt, C., and Kirst, G.O. 1996. Dimethylsulfoniopropionate production in phototrophic organisms and its physiological function as a cryoprotectant. In Biological and environmental chemistry of DMSP and related sulfonium compounds. Edited by R.P. Kiene, P.T. Visscher, M.D. Keller, and G.O. Kirst. Plenum, New York. pp. 143-153.

Klumpp, D.W., and Griffiths, C.L. 1994. Contributions of phototrophic and heterotrophic nutrition to the metabolic and growth requirements of four species of giant clam (Tridacnidae). Mar. Ecol. Prog. Ser. 115: 103-115.

Levasseur, M., Keller, M.D., Bonneau, E., D’Amours, D., and Bellows, W.K. 1994. Oceanographic basis of a DMS-related Atlantic cod (Gadus morhua) fishery problem: blackberry feed. Can. J. Fish. Aquat. Sci. 51: 881-889.

Nishiguchi, M.K., and Somero, G.N. 1992. Temperature- and concentration-dependence of compatibility of the organic osmolyte $\beta$-dimethylsulfoniopropionate. Cryobiology, 29: 118 124.

Norton, J.H., Shepherd, M.A., Long, H.M., and Fitt, W.K. 1992. The zooxanthellal tubular system in the giant clam. Biol. Bull. (Woods Hole), 183: 503-506.

Peavey, S., and Riley, J. 1993. Sensory evaluation of fresh and frozen giant clams. Res. Rep. 93-02. National Aquaculture Center, Federated States of Micronesia. (Available from the senior author of this paper.)

Peavey, S., and Riley, J. 1994. Marketing giant clams in the local foodservice industry: a case study. Res. Rep. 94-01. National Aquaculture Center, Federated States of Micronesia. (Available from the senior author of this paper.)

Rowan, R. 1998. Diversity and ecology of zooxanthellae on coral reefs. J. Phycol. 34: 407-417.

Sunda, W., Kieber, D.J., Kiene, R.P., and Huntsman, S. 2002. An antioxidant function for DMSP and DMS in marine algae. Nature (Lond.), 418: 317-320. 